\title{
Awareness assessment in Turkish subpopulation with chronic oral mucosal diseases
}

\author{
Ozlem Okumus ${ }^{1}$, Sevda Kalkan ${ }^{1}$, Gaye Keser ${ }^{1}$, Filiz Namdar Pekiner ${ }^{1}$
}

Correspondence: Dr. Filiz Namdar Pekiner

Email: fpekiner@gmail.com
'Department of Oral Diagnosis and Radiology, Faculty of Dentistry, Marmara University, Istanbul, Turkiye

\section{ABSTRACT}

Objectives: The aim of this study was to evaluate the awareness of group Turkish patients with chronic oral mucosal diseases by chronic oral mucosal diseases questionnaires (COMDQ). Materials and Methods: Eighty patients with chronic oral mucosal diseases were participated in the study. A detailed medical history of each patient was taken, and all the COMDQ questions, which were translated from English version, were filled out. The data were analyzed with the IBM Statistical Package for Social Sciences Statistics 22.0. Results: The mean ages of patients were $48.91 \pm 13.36$ years. Of the total 80 cases of chronic oral mucosal diseases identified $52(65 \%)$ were female and $28(35 \%)$ male. The standardized mean scores for COMDQ were $1.72 \pm 1.11$ for "pain and functional limitation," $1.09 \pm 0.94$ for "medication and treatment," $2.31 \pm 1.06$ for "social and emotional," and $2.27 \pm 0.83$ for "patient support," respectively. Conclusions: The results of this study indicate that the Turkish version of the COMDQ has the profitable psychometric peculiarity and comfortable to patients with chronic oral mucosal diseases in Turkey.

Key words: Awareness, chronic oral mucosal diseases, quality of life

\section{INTRODUCTION}

Chronic oral mucosal diseases are a group of diseases including autoimmune, inflammatory, and infectious conditions that can affect the oral mucosa. These conditions can result in substantial morbidity with the emotional and functional outcome for patients. ${ }^{[1]}$ Oral diseases can change an aspect and cause to decline in interpersonal and family relationships. In addition, they have harmful impaction on speaking, mastication, and self-respect. ${ }^{[2-4]}$ The chronic oral mucosal diseases not only affect the daily lives of patients but also can affect the patients' quality of life (QoL) with various treatment options and their side effects. These conditions critically disturb life quality in most people and can influence diverse of life such as nutrition, chewing, aspect, and social interaction.

Knowledge concerning the effect of oral mucosal diseases on life quality is an identified requirement. Hence, the most of the various patients based oral health status measurements have been improved over the past decade to evaluate the emotional, functional, psychosocial outcomes of oral mucosal diseases, and the influence of oral health situation on life quality. ${ }^{[5]}$ The measurements enhance the connection between patients and clinicians and supply better knowledge of the impact of oral disorders on life quality. ${ }^{[5-7]}$

According to the World Health Organization, QoL is described as a personal sensation of his/her status in life in the cultural context in which she/he lives and concerning his/her aims, hopes, and standards. ${ }^{[5]}$ The patient centered measurements of oral health conditions were first identified by Cohen and Jago ${ }^{[8]}$ in 1976, who defined the deficit of information regarding the psychosocial effect of oral health issue. Conversely, Cohen and Jago ${ }^{[8]}$ the relation to the social impact of the oral disease was described using societal indicators by Reisine. ${ }^{[9]} \mathrm{A}$ number of researchers have employed oral specific health measures. Hence,

This is an open access article distributed under the terms of the Creative Commons Attribution-NonCommercial-ShareAlike 3.0 License, which allows others to remix, tweak, and build upon the work non-commercially, as long as the author is credited and the new creations are licensed under the identical terms.

For reprints contact: reprints@medknow.com

How to cite this article: Okumus O, Kalkan S, Keser G, Pekiner FN. Awareness assessment in Turkish subpopulation with chronic oral mucosal diseases. Eur J Dent 2015;9:564-72.

DOI: $10.4103 / 1305-7456.172633$ 
the various psychometric measurements have been used to measure oral health-related quality of life (OHQoL)..$^{[10]}$

The QoL measurement instruments can be divided into generic, disease-specific, and discipline-specific questionnaires. ${ }^{[11,12]}$ Generic QoL questionnaires cannot detect small, clinically important changes related with a specific disease, but they allow to make comparisons between different diseases. Disease-specific questionnaires accurately predict clinical changes related with a specific disease but do not let to make a comparison against diseases. ${ }^{[5,11-15]}$ Chronic oral mucosal diseases questionnaires (COMDQ) is a discipline-specific questionnaire developed for the area of oral medicine and radiology. ${ }^{[5]}$

COMDQ has been recently developed that consists of 26 items. The items are sorted accordingly clinical decision into four domains; pain and functional limitation, medications and side effects, social and emotional, and patient support. ${ }^{[5,12,16]}$

A variety of patients based outcome instruments called "OHQoL measures" have been improved. ${ }^{[17,18]}$ "OHQoL" centered on the appearances of individual life affected by oral health issues and assess as a multidimensional properties, which comprises not just physical functioning and pain, but also psychosocial functioning, mental health, appearance, and life satisfaction. ${ }^{[2,19,20]}$ In this study, the COMDQ have used, and it was translated into Turkish, so we evaluated the availability of the questionnaire in Turkish patients.

Therefore, the aim of this study was to evaluate the awareness of group Turkish patients with chronic oral mucosal diseases by COMDQ.

\section{MATERIALS AND METHODS}

\section{Subjects}

Eighty patients with chronic oral mucosal diseases attending the Department of Oral Diagnosis and Radiology of Marmara University of Faculty of Dentistry were participated in this study. Overall, 80 cases of oral mucosal diseases included burning mouth syndrome, geographic tongue, gingival pigmentation, erosive cheilitis, hemangioma, hyperkeratosis, lichen planus, lichenoid reaction, lipom, oral leukoplakia, papillamatous, pyogenic granuloma, changes related to prosthesis, pseudoxanthoma elasticum, recurrent aphthous stomatitis, squamous cell carcinoma, changes to related trauma and vesicobullous diseases. A detailed medical history of each patient was taken and prediagnosed patients were told about the content of the questionnaire. Those who want to participate in the questionnaire have included. The patient's sociodemographic information of age, gender, and work were assessed. This study was performed according to the guidelines at the declaration of Helsinki concerning ethical principles for medical research involving human subjects. Due to the retrospective nature of this study, ethical board approval was not by local laws and regulations, and the informed consent requirement was waived by the departments where the study was carried out.

\section{The instrument}

COMDQ is an OHQoL instrument containing 26 items. The items are sorted accordingly clinical decision into four domains: Pain and functional limitation (nine items), medication and treatment (six items), social and emotional (seven items), and patient support (four items). For each item, patients answered by using a Likert-type response scale coded. Responses were coded $0=$ "not at all," $1=$ "slightly," $2=$ "moderately," $3=$ "considerably," $4=$ "extremely" [Table 1].

\section{Statistical analysis}

The data were analyzed with the IBM Statistical Package for Social Sciences for Windows 22.0 (Armonk, New York: IBM Corp). Descriptive statistical methods (mean and frequency) were used for evaluation of the data. The Kruskal-Wallis test was used to evaluate comparisons between quantitative data. Statistical significance of differences among the groups was determined by Mann-Whitney U-test (for nonparametric distribution). The values of $P<0.05$ were interpreted as significant.

\section{RESULTS}

\section{Patient characteristics}

Eighty patients (52 female and 28 male) with chronic oral mucosal diseases were enrolled in the study. The patients were aged 19-79 and the average age was $48.91 \pm 13.36$. Of the total 80 cases of chronic oral mucosal diseases identified $33(41.3 \%)$ were employed, 35 (43.8\%) unemployed, and 12 (15\%) retired. Among these 80 patients, the most common was burning mouth syndrome (20\%), lichen planus $(15 \%)$, and changes to related trauma $(14.6 \%)$ were followed. The standardized mean scores for COMDQ were $1.72 \pm 1.11$ for "pain and functional limitation," $1.09 \pm 0.94$ for "medication and treatment," $2.31 \pm 1.06$ 


\section{Table 1: Chronic oral mucosal diseases questionnaire (14)}

Pain and functional limitation

1. How much do certain types of food/drink causes you discomfort (spicy food, acidic food)?

2. How much does your oral condition cause you to limit the types of food/drinks you consume?

3. How much do certain food textures causes you discomfort (rough food, crusty food)?

4. How much does your oral condition cause you to limit the textures of the food you consume?

5. How much does the temperature of certain foods/drinks cause you discomfort?

6. How much does your oral condition cause you to limit the temperature of the foods/drinks you consume?

7. How much does your oral condition lead to discomfort when carrying out your daily oral hygiene routine?

8. How much does your oral condition cause you to limit your daily oral hygiene routine?

9. How much does your oral condition lead to discomfort when wearing a denture (false teeth)?

Medication and treatment

1. How much do you feel you need medication to help you

with activities of daily life (talking, eating, etc.)?

\begin{tabular}{|c|c|}
\hline Not at all & $\square 0$ \\
\hline Slightly & $\square 1$ \\
\hline Moderately & $\square 2$ \\
\hline Considerably & $\square 3$ \\
\hline Extremely & $\square 4$ \\
\hline Not at all & $\square 0$ \\
\hline Slightly & $\square 1$ \\
\hline Moderately & $\square 2$ \\
\hline Considerably & $\square 3$ \\
\hline Extremely & $\square 4$ \\
\hline Not at all & $\square 0$ \\
\hline Slightly & $\square 1$ \\
\hline Moderately & $\square 2$ \\
\hline Considerably & $\square 3$ \\
\hline Extremely & $\square 4$ \\
\hline Not at all & $\square 0$ \\
\hline Slightly & $\square 1$ \\
\hline Moderately & $\square 2$ \\
\hline Considerably & $\square 3$ \\
\hline Extremely & $\square 4$ \\
\hline Not at all & $\square 0$ \\
\hline Slightly & $\square 1$ \\
\hline Moderately & $\square 2$ \\
\hline Considerably & $\square 3$ \\
\hline Extremely & $\square 4$ \\
\hline Not at all & $\square 0$ \\
\hline Slightly & $\square 1$ \\
\hline Moderately & $\square 2$ \\
\hline Considerably & $\square 3$ \\
\hline Extremely & $\square 4$ \\
\hline Not at all & $\square 0$ \\
\hline Slightly & $\square 1$ \\
\hline Moderately & $\square 2$ \\
\hline Considerably & $\square 3$ \\
\hline Extremely & $\square 4$ \\
\hline Not at all & $\square 0$ \\
\hline Slightly & $\square 1$ \\
\hline Moderately & $\square 2$ \\
\hline Considerably & $\square 3$ \\
\hline Extremely & $\square 4$ \\
\hline Not at all & $\square 0$ \\
\hline Slightly & $\square 1$ \\
\hline Moderately & $\square 2$ \\
\hline Considerably & $\square 3$ \\
\hline Extremely & $\square 4$ \\
\hline Not at all & $\square 0$ \\
\hline Slightly & $\square 1$ \\
\hline Moderately & $\square 2$ \\
\hline Considerably & $\square 3$ \\
\hline Extremely & $\square 4$ \\
\hline
\end{tabular}


Okumus, et al:: Awareness assessment with oral mucosal diseases

\section{Table 1: Contd...}

2. How satisfied are you with the medication being used to treat your oral condition?

3. How concerned are you about the possible side effects of the medications used to treat your oral condition?

4. How much does it frustrate you that there is no single standard medication to be used in your oral condition?

5. How much does the use of the medication limit you in your everyday life?

6. How much does it bother you that there is no cure for your oral condition?

Social and emotional

1. How much does your oral condition get you down?

2. How much does your oral condition cause you anxiety?

3. How much does your oral condition cause you stress?

4. How much does the unpredictability of your oral condition bother you?

5. How much does your oral condition cause you to worry about the future?

6. How much does your oral condition make you pessimistic about the future?

\begin{tabular}{|c|c|}
\hline Not at all & $\square 0$ \\
\hline Slightly & $\square 1$ \\
\hline Moderately & $\square 2$ \\
\hline Considerably & $\square 3$ \\
\hline Extremely & $\square 4$ \\
\hline Not at all & $\square 0$ \\
\hline Slightly & $\square 1$ \\
\hline Moderately & $\square 2$ \\
\hline Considerably & $\square 3$ \\
\hline Extremely & $\square 4$ \\
\hline Not at all & $\square 0$ \\
\hline Slightly & $\square 1$ \\
\hline Moderately & $\square 2$ \\
\hline Considerably & $\square 3$ \\
\hline Extremely & $\square 4$ \\
\hline Not at all & $\square 0$ \\
\hline Slightly & $\square 1$ \\
\hline Moderately & $\square 2$ \\
\hline Considerably & $\square 3$ \\
\hline Extremely & $\square 4$ \\
\hline Not at all & $\square 0$ \\
\hline Slightly & $\square 1$ \\
\hline Moderately & $\square 2$ \\
\hline Considerably & $\square 3$ \\
\hline Extremely & $\square 4$ \\
\hline Not at all & $\square 0$ \\
\hline Slightly & $\square 1$ \\
\hline Moderately & $\square 2$ \\
\hline Considerably & $\square 3$ \\
\hline Extremely & $\square 4$ \\
\hline Not at all & $\square 0$ \\
\hline Slightly & $\square 1$ \\
\hline Moderately & $\square 2$ \\
\hline Considerably & $\square 3$ \\
\hline Extremely & $\square 4$ \\
\hline Not at all & $\square 0$ \\
\hline Slightly & $\square 1$ \\
\hline Moderately & $\square 2$ \\
\hline Considerably & $\square 3$ \\
\hline Extremely & $\square 4$ \\
\hline Not at all & $\square 0$ \\
\hline Slightly & $\square 1$ \\
\hline Moderately & $\square 2$ \\
\hline Considerably & $\square 3$ \\
\hline Extremely & $\square 4$ \\
\hline Not at all & $\square 0$ \\
\hline Slightly & $\square 1$ \\
\hline Moderately & $\square 2$ \\
\hline Considerably & $\square 3$ \\
\hline Extremely & $\square 4$ \\
\hline Not at all & $\square 0$ \\
\hline Slightly & $\square 1$ \\
\hline Moderately & $\square 2$ \\
\hline Considerably & $\square 3$ \\
\hline Extremely & $\square 4$ \\
\hline
\end{tabular}




\begin{tabular}{|c|c|c|}
\hline \multirow{5}{*}{$\begin{array}{l}\text { 7. How much does your oral condition disrupt social activities } \\
\text { in your life (social gatherings, eating out parties)? }\end{array}$} & Not at all & $\square 0$ \\
\hline & Slightly & $\square 1$ \\
\hline & Moderately & $\square 2$ \\
\hline & Considerably & $\square 3$ \\
\hline & Extremely & $\square 4$ \\
\hline \multicolumn{3}{|l|}{ Patient support } \\
\hline \multirow{5}{*}{$\begin{array}{l}\text { 1. How satisfactory do you consider the information available } \\
\text { to you regarding your oral condition? }\end{array}$} & Not at all & $\square 0$ \\
\hline & Slightly & $\square 1$ \\
\hline & Moderately & $\square 2$ \\
\hline & Considerably & $\square 3$ \\
\hline & Extremely & $\square 4$ \\
\hline \multirow{5}{*}{$\begin{array}{l}\text { 2. How satisfied are you with the level of support and understanding } \\
\text { shown to you by the family regarding this oral condition? }\end{array}$} & Not at all & $\square 0$ \\
\hline & Slightly & $\square 1$ \\
\hline & Moderately & $\square 2$ \\
\hline & Considerably & $\square 3$ \\
\hline & Extremely & $\square 4$ \\
\hline \multirow{5}{*}{$\begin{array}{l}\text { 3. How satisfied are you with the level of support and understanding shown } \\
\text { to you by friends'work colleagues regarding your oral condition? }\end{array}$} & Not at all & $\square 0$ \\
\hline & Slightly & $\square 1$ \\
\hline & Moderately & $\square 2$ \\
\hline & Considerably & $\square 3$ \\
\hline & Extremely & $\square 4$ \\
\hline \multirow[t]{5}{*}{ 4. How isolated do you feel as a result of this oral condition? } & Not at all & $\square 0$ \\
\hline & Slightly & $\square 1$ \\
\hline & Moderately & $\square 2$ \\
\hline & Considerably & $\square 3$ \\
\hline & Extremely & $\square 4$ \\
\hline
\end{tabular}

for "social and emotional," and $2.27 \pm 0.83$ for "patient support," respectively. The median scores of patients' answers to COMDQ questionnaire are shown in Table 2.

\section{Assessments related gender}

The score of social and emotional in female was statistically significantly higher than male $(P<0.05)$ [Table 3]. Significant differences were not observed among the genders for the other domains $(P>0.05)$.

\section{Assessments related ages groups}

The scores of pain and functional limitation were shown statistically significant difference $(P<0.05)$. In under the age of 45 , the scores were determined significantly higher than the age of 45 and older [Table 4]. Significant age-related differences were not observed in the other domains $(P>0.05)$.

\section{Assessments related employment state}

The scores of pain and functional limitation were shown statistically significant difference $(P<0.05)$. As a result of the dual comparison, unemployed group scores were determined significantly higher than retired group $(P<0.05)$. There were no statistically significant differences between the other groups $(P>0.05)$ [Table 5].
The scores of medication and treatment were shown statistically significant difference $(P<0.05)$. As a result of the dual comparison, the employed and unemployed group scores were determined significantly higher than retired group $(P<0.05)$. There were no statistically significant differences between the other groups $(P>0.05)$ [Table 5].

The scores of social and emotional were shown statistically significant difference $(P<0.05)$. As a result of the dual comparison, the employed and unemployed group scores were determined significantly higher than retired group $(P<0.05)$. There were no statistically significant differences between the other groups $(P>0.05)$ [Table 5].

According to employment state, the scores of patient support were not shown statistically significant difference $(P>0.05)$ [Table 5].

\section{Assessments related diseases}

According to diseases, the groups that a number of cases below five were not evaluated. The groups that a number of cases were more than five were evaluated. The scores of "pain and functional limitation," "medication and treatment," "social and emotional," 
Okumus, et al:: Awareness assessment with oral mucosal diseases

\begin{tabular}{|c|c|c|c|c|c|c|}
\hline & \multicolumn{6}{|c|}{$n(\%)$} \\
\hline & Not at all & Slightly & Moderately & Considerably & Extremely & Mean $\pm S D$ \\
\hline Pain and functional limitation & & & & & & $1.72 \pm 1.11$ \\
\hline 1 & $18(22.5)$ & $17(21.3)$ & $16(20)$ & $20(25)$ & $9(11.3)$ & $1.81 \pm 1.34$ \\
\hline 2 & $29(36.3)$ & $14(17.5)$ & $10(12.5)$ & $18(22.5)$ & $9(11.3)$ & $1.55 \pm 1.46$ \\
\hline 3 & $25(31.3)$ & $13(16.3)$ & $10(12.5)$ & $17(21.3)$ & $15(18.3)$ & $1.80 \pm 1.54$ \\
\hline 4 & $27(33.8)$ & $14(17.5)$ & $11(13.8)$ & $14(17.5)$ & $14(17.5)$ & $1.68 \pm 1.52$ \\
\hline 5 & $28(35)$ & $18(22.5)$ & $8(10)$ & $11(13.8)$ & $15(18.8)$ & $1.59 \pm 1.54$ \\
\hline 6 & $31(38.8)$ & $15(18.8)$ & $11(13.8)$ & $12(15)$ & $11(13.8)$ & $1.46 \pm 1.48$ \\
\hline 7 & $26(32.5)$ & $21(26.3)$ & $6(7.5)$ & $21(26.3)$ & $6(7.5)$ & $1.50 \pm 1.38$ \\
\hline 8 & $36(45)$ & $14(17.5)$ & $8(10)$ & $18(22.5)$ & $4(5)$ & $1.25 \pm 1.36$ \\
\hline 9 & $25(31.3)$ & $6(7.5)$ & $4(5)$ & $5(6.3)$ & $40(50.1)$ & $2.86 \pm 2.28$ \\
\hline Medication and treatment & & & & & & $1.09 \pm 0.94$ \\
\hline 1 & $54(67.5)$ & $7(8.8)$ & $8(10)$ & $8(10)$ & $3(3.8)$ & $0.74 \pm 1.21$ \\
\hline 2 & $43(53.8)$ & $9(11.3)$ & $7(8.8)$ & $12(15)$ & $9(11.3)$ & $1.19 \pm 1.49$ \\
\hline 3 & $49(61.3)$ & $13(16.3)$ & $3(3.8)$ & $8(10)$ & $7(8.8)$ & $0.89 \pm 1.36$ \\
\hline 4 & $43(53.8)$ & $6(7.5)$ & $9(11.3)$ & $10(12.5)$ & $12(15)$ & $1.28 \pm 1.57$ \\
\hline 5 & $53(66.6)$ & $11(13.8)$ & $10(12.5)$ & $5(6.3)$ & $1(1.3)$ & $0.63 \pm 1.01$ \\
\hline 6 & $34(42.5)$ & $5(6.3)$ & $7(8.8)$ & $11(13.8)$ & $23(28.8)$ & $1.80 \pm 1.75$ \\
\hline Social and emotional & & & & & & $2.31 \pm 1.06$ \\
\hline 1 & $3(3.8)$ & $12(15)$ & $13(16.3)$ & $19(23.8)$ & $33(41.3)$ & $2.84 \pm 1.23$ \\
\hline 2 & $5(6.3)$ & $12(15)$ & $16(20)$ & $20(25)$ & $27(33.8)$ & $2.65 \pm 1.26$ \\
\hline 3 & $5(6.3)$ & $11(13.8)$ & $17(21.3)$ & $20(25)$ & $27(33.8)$ & $2.66 \pm 1.25$ \\
\hline 4 & $17(21.3)$ & $7(8.8)$ & $10(12.5)$ & $21(26.3)$ & $25(31.3)$ & $2.38 \pm 1.53$ \\
\hline 5 & $11(13.8)$ & $12(15)$ & $14(17.5)$ & $23(28.8)$ & $20(25)$ & $2.36 \pm 1.37$ \\
\hline 6 & $21(26.3)$ & $12(15)$ & $10(12.5)$ & $30(37.5)$ & $7(8.8)$ & $1.88 \pm 1.39$ \\
\hline 7 & $34(42.5)$ & $14(17.5)$ & $12(15)$ & $7(8.8)$ & $13(16.3)$ & $1.39 \pm 1.51$ \\
\hline Patient support & & & & & & $2.27 \pm 0.83$ \\
\hline 1 & $6(7.5)$ & $7(8.8)$ & $8(10)$ & $24(30)$ & $35(43.8)$ & $2.94 \pm 1.26$ \\
\hline 2 & $11(13.8)$ & $2(2.5)$ & $5(6.3)$ & $26(32.5)$ & $36(45)$ & $2.93 \pm 1.37$ \\
\hline 3 & $14(17.5)$ & $4(5)$ & $10(12.5)$ & $36(45)$ & $16(20)$ & $2.45 \pm 1.35$ \\
\hline 4 & $51(63.8)$ & $13(16.3)$ & $5(6.3)$ & $6(7.5)$ & $5(6.3)$ & $0.76 \pm 1.23$ \\
\hline
\end{tabular}

\section{Table 3: Assessments related gender}

Female

Mean \pm SD

Pain and functional limitation $1.81 \pm 1.13$ (1.56) $1.56 \pm 1.08(1.56) \quad 0.405$

Medication and treatment $1.21 \pm 0.97(1.17) \quad 0.86 \pm 0.85(0.75) \quad 0.142$

Social and emotional $\quad 2.51 \pm 0.99(2.57) 1.93 \pm 1.09(2.14) 0.023^{*}$

Patient support $\quad 2.28 \pm 0.79(2.25) \quad 2.25 \pm 0.93(2.5) \quad 0.648$

Mann-Whitney U-test. ${ }^{*} P<0.05$. SD: Standard deviation

\section{Table 4: Assessments related age groups}

Mean $\pm S D$
$<45$ years $\geq 45$ years

Pain and functional limitation $2.19 \pm 1.28$ (2.44) $1.48 \pm 0.94$ (1.33) $0.011^{*}$ Medication and treatment $1.36 \pm 0.99(1.5) \quad 0.96 \pm 0.88(0.83) \quad 0.079$ Social and emotional $\quad 2.61 \pm 1.10(2.86) 2.15 \pm 1.01(2.14) \quad 0.059$ $\begin{array}{llll}\text { Patient support } & 2.48 \pm 0.83(2.5) & 2.16 \pm 0.82(2.25) & 0.097\end{array}$

Mann-Whitney U-test. ${ }^{*} P<0.05$. SD: Standard deviation

and "patient support" support were not shown statistically significant difference $(P>0.05)$ [Table 6].

\section{DISCUSSION}

To our knowledge, the present study was the first study evaluating the psychometric properties of the COMDQ in Turkish patients. QoL measures are increasingly being used for evaluate the perceived impact of oral health in different patient populations. It is important to detect the character of the plaints that lead patients to look for a cure and to what degree these influence patients' life quality. ${ }^{[21]}$ Therefore, there is an increasing need for use in different languages.

When reviewed the literatures, COMDQ was not used in Turkish population before but also other similar measures were used. Mumcu et al. ${ }^{[2]}$ evaluated the multidimensional concept of oral health impact profile-14 (OHIP-14) in Behçet's disease and recurrent aphthous stomatitis. The study was found that OHIP-14 was easy and useful enough for clinicians and patients to use and evaluate. In the other study, 
Okumus, et al:: Awareness assessment with oral mucosal diseases

\begin{tabular}{|c|c|c|c|c|}
\hline & \multicolumn{3}{|c|}{ Employment state (mean $\pm S D$ ) } & \multirow[t]{2}{*}{$P$} \\
\hline & Employed & Unemployed & Retired & \\
\hline Pain and functional limitation & $1.64 \pm 0.16(1.56)$ & $1.98 \pm 1.0(1.56)$ & $1.19 \pm 1.14(0.78)$ & $0.047^{*}$ \\
\hline Medication and treatment & $1.06 \pm 0.86(0.83)$ & $1.33 \pm 1.03(1.5)$ & $0.46 \pm 0.51(0.33)$ & $0.034^{*}$ \\
\hline Social and emotional & $2.27 \pm 1.17(2.43)$ & $2.62 \pm 0.85(2.71)$ & $1.49 \pm 0.88(1.71)$ & $0.006^{* *}$ \\
\hline Patient support & $2.32 \pm 0.91(2.75)$ & $2.19 \pm 0.87(2.25)$ & $2.37 \pm 0.42(2.25)$ & 0.436 \\
\hline
\end{tabular}

\begin{tabular}{|c|c|c|c|c|c|}
\hline \multirow[t]{2}{*}{ Disease } & \multirow[t]{2}{*}{$n$} & \multicolumn{4}{|c|}{ Mean \pm SD } \\
\hline & & $\begin{array}{c}\text { Pain and functional } \\
\text { limitation }\end{array}$ & $\begin{array}{l}\text { Medication } \\
\text { and treatment }\end{array}$ & $\begin{array}{l}\text { Social and } \\
\text { emotional }\end{array}$ & $\begin{array}{l}\text { Patient } \\
\text { support }\end{array}$ \\
\hline Burning mouth syndrome & 16 & $1.33 \pm 0.86(1.2)$ & $0.83 \pm 0.92(0.7)$ & $2.41 \pm 0.82(2.4)$ & $2.27 \pm 0.84(2.3)$ \\
\hline Geographic tongue & 1 & 2.11 & 1.83 & 3.29 & 1.75 \\
\hline Gingival pigmentation & 2 & $0.22 \pm 0(0.2)$ & $0.25 \pm 0.35(0.3)$ & $2.14 \pm 0.61(2.1)$ & $2.5 \pm 0.35(2.5)$ \\
\hline Erosive cheilitis & 2 & $1.83 \pm 2.44(1.8)$ & $1.08 \pm 1.06(1.1)$ & $2.86 \pm 1.01(2.9)$ & $2.38 \pm 0.18(2.4)$ \\
\hline Hemangioma & 3 & $1.37 \pm 1.18(1.6)$ & $1.39 \pm 0.75(1.3)$ & $2.62 \pm 2.02(3.7)$ & $3.25 \pm 0.66(3)$ \\
\hline Hyperkeratosis & 4 & $2.03 \pm 1.12(1.9)$ & $0.71 \pm 0.7(0.6)$ & $2.54 \pm 0.98(2.8)$ & $1.94 \pm 0.83(2)$ \\
\hline Lichen planus & 12 & $1.65 \pm 1.08(1.4)$ & $1.18 \pm 0.98(1.3)$ & $2.1 \pm 1.09(2.1)$ & $2.25 \pm 0.78(2.3)$ \\
\hline Lichenoid reaction & 5 & $2.4 \pm 1.2(2.6)$ & $1.2 \pm 1.31(0.8)$ & $2.66 \pm 0.59(2.7)$ & $2.4 \pm 0.38(2.3)$ \\
\hline Lipom & 1 & 0.44 & 0 & 0 & 2.25 \\
\hline Oral leukoplakia & 3 & $0.85 \pm 0.67(0.8)$ & $1.33 \pm 0.88(1)$ & $1.62 \pm 1.35(1.1)$ & $2.42 \pm 0.52(2.3)$ \\
\hline Papillamatous & 1 & 1.56 & 2.67 & 2.86 & 2.75 \\
\hline Pyogenic granuloma & 1 & 1.22 & 0 & 1.86 & 3 \\
\hline Changes related to prosthesis & 5 & $1.13 \pm 0.74(1.6)$ & $0.57 \pm 0.8(0)$ & $1.51 \pm 0.98(1.3)$ & $1.6 \pm 1.28(1.5)$ \\
\hline Pseudoxanthoma elasticum & 1 & 2.78 & 1.83 & 4 & 3.5 \\
\hline Recurrent aphthous stomatitis & 6 & $2.67 \pm 1.33(3.2)$ & $1.58 \pm 0.97(1.6)$ & $3.02 \pm 0.67(3.1)$ & $2.08 \pm 1.25(2.3)$ \\
\hline Squamous cell carcinoma & 1 & 1.56 & 0 & 0 & 3 \\
\hline Changes to related trauma & 10 & $2.01 \pm 1.15(1.9)$ & $1.1 \pm 0.83(1.2)$ & $2.2 \pm 1.06(2.3)$ & $2.33 \pm 0.72(2.5)$ \\
\hline Vesicobullous diseases & 6 & $2.39 \pm 1.02(2.8)$ & $1.67 \pm 0.95(1.4)$ & $2.5 \pm 1.1(2.2)$ & $1.96 \pm 0.94(1.8)$ \\
\hline$P$ & & 0.120 & 0.333 & 0.279 & 0.878 \\
\hline
\end{tabular}

evaluated and compared OHQoL in patients from UK and Turkey with Behcet's disease by using OHIP-14. ${ }^{[22]}$ The comparison results showed that patients from UK and Turkey had the same impairment in their oral QoL status. Furthermore, Mumcu et al.[23] investigated oral and general health related QoL in patients with Behçet's disease and assessed the yield of Turkish versions of OHIP-14, OHQoL, and short form-36 (SF-36) questionnaires. OHIP-14 and OHQoL are specific questionnaires for oral health and SF-36 is the general measure of health status. The study demonstrated that both specific and general questionnaires scores were significantly worse in patients with Behçet's disease. In the other study in Turkey, determined which complaints cause patients to come to their clinic and to what degree those complaints affect their QoL. ${ }^{[21]}$

Min et al. ${ }^{[12]}$ found that the Chinese version of the COMDQ has good reliability and validity can be applicable to assess the QHRoL of patients with chronic oral mucosal diseases in China. Similarly, in our study found that the Turkish version of COMDQ is applicable and can be used in evaluating in QoL of patients.

Our study demonstrated that in under the age of 45 the scores were determined significantly higher than the age of older in the domain pain and functional limitation. Likewise, Bijina et al. ${ }^{[5]}$ evaluated 45 and the QoL in patients with chronic oral mucosal diseases by COMDQ, and the older patients were reported significantly lower score. Furthermore, in our study, in the domain of social and emotional scores were showed a higher in female than male. Contrary, in that study male reported significantly higher oral health related than female in pain and functional limitation.

Furthermore, Baker et al. ${ }^{[24]}$ reported data on QoL measures in patients xerostomia by using OHIP-14 
and oral impacts on daily performance measures, which had good psychometric features as measured in that study. Moreover, Hegarty et al. ${ }^{[25]}$ studied the relevance of QoL measures, which were UK (OHQoL-UK) and OHIP-14 in oral lichen planus. The results of this study showed that both questionnaires performed well in the assessment of patients with oral lichen planus.

Locker and Allen ${ }^{[26]}$ described OHQoL as the effect of oral diseases in daily life that is substantial to patients and reported that the instruments used in oral health examination supply accurate knowledge.

The generic and specific instruments have some advantages and disadvantages. In a previous study published that the comparison of dimensions of OHQoL measured by a generic health state measure and a specific oral health measure. ${ }^{[27]}$

OHIP is one of the most commonly used to measure patient's sensation of the influence of oral diseases on their life. The questionnaire was used previously in many different populations. . $^{[2,6,7,28-30]}$

However, some limitations should be considered when interpreting the results. One of them, there is the inhomogeneous distribution of the gender; the majority of patients were female. Furthermore, heterogeneity in age and deficiency in the number of patients might not allow to generalize our findings to the general populations. Further longitudinal studies should be required to generalize.

\section{CONCLUSION}

Chronic oral mucosal diseases are common and the perspicuity and medicinal management of these situations can have an efficacy on the daily lives of patients. Qol measurements can play a key role by helping evaluate the dimensions of the disease and its treatment. Our findings suggest that the Turkish version of COMDQ is applicable and can be used in evaluating QoL of patients. This assessment is so important to determine the patient's QoL.

\section{Acknowledgments}

This study is presented in $12^{\text {th }}$ Biennial Congress of EAOM, Antalya, Turkey, September 11-13, 2014.

\section{Financial support and sponsorship}

Nil.

\section{Conflicts of interest}

There are no conflicts of interest.

\section{REFERENCES}

1. Ni Riordain R, Meaney S, McCreary C. Impact of chronic oral mucosal disease on daily life: Preliminary observations from a qualitative study. Oral Dis 2011;17:265-9.

2. Mumcu G, Hayran O, Ozalp DO, Inanc N, Yavuz S, Ergun T, et al. The assessment of oral health-related quality of life by factor analysis in patients with Behcet's disease and recurrent aphthous stomatitis. J Oral Pathol Med 2007;36:147-52.

3. Scheffel DL, Jeremias F, Fragelli CM, Dos Santos-Pinto LA, Hebling J, de Oliveira OB Jr. Esthetic dental anomalies as motive for bullying in schoolchildren. Eur J Dent 2014;8:124-8.

4. Koruyucu M, Bayram M, Tuna EB, Gencay K, Seymen F. Clinical findings and long-term managements of patients with amelogenesis imperfecta. Eur J Dent 2014;8:546-52.

5. Rajan B, Ahmed J, Shenoy N, Denny C, Ongole R, Binnal A. Assessment of quality of life in patients with chronic oral mucosal diseases: A questionnaire-based study. Perm J 2014;18:e123-7.

6. Liu LJ, Xiao W, He QB, Jiang WW. Generic and oral quality of life is affected by oral mucosal diseases. BMC Oral Health 2012;12:2.

7. Souza FT, Santos TP, Bernardes VF, Teixeira AL, Kümmer AM, Silva TA, et al. The impact of burning mouth syndrome on health-related quality of life. Health Qual Life Outcomes 2011;9:57.

8. Cohen LK, Jago JD. Toward the formulation of sociodental indicators. Int J Health Serv 1976;6:681-98.

9. Reisine ST. Dental disease and work loss. J Dent Res 1984;63:1158-61.

10. Sixou JL. How to make a link between Oral Health-Related Quality of Life and dentin hypersensitivity in the dental office? Clin Oral Investig 2013;17 Suppl 1:S41-4.

11. Ni Riordain R, Meaney S, McCreary C. A patient-centered approach to developing a quality-of-life questionnaire for chronic oral mucosal diseases. Oral Surg Oral Med Oral Pathol Oral Radiol Endod 2011;111:578-86, 586.e1-2.

12. Li M, He SL. Reliability and validity of the Chinese version of the chronic oral mucosal diseases questionnaire. J Oral Pathol Med 2013;42:194-9.

13. Ni Riordain R, McCreary C. Validity and reliability of a newly developed quality of life questionnaire for patients with chronic oral mucosal diseases. J Oral Pathol Med 2011;40:604-9.

14. Lee GH, McGrath C, Yiu CK, King NM. A comparison of a generic and oral health-specific measure in assessing the impact of early childhood caries on quality of life. Community Dent Oral Epidemiol 2010;38:333-9.

15. Suliman NM, Johannessen AC, Ali RW, Salman H, Astrøm AN Influence of oral mucosal lesions and oral symptoms on oral health related quality of life in dermatological patients: A cross sectional study in Sudan. BMC Oral Health 2012;12:19.

16. Ni Riordain R, McCreary C. Further reliability and responsiveness of the Chronic Oral Mucosal Diseases Questionnaire. Oral Dis 2012;18:60-6.

17. Allen PF. Assessment of oral health related quality of life. Health Qual Life Outcomes 2003 8;1:40.

18. McGrath C, Hegarty AM, Hodgson TA, Porter SR. Patient-centred outcome measures for oral mucosal disease are sensitive to treatment. Int J Oral Maxillofac Surg 2003;32:334-6.

19. Llewellyn $C D$, Warnakulasuriya $S$. The impact of stomatological disease on oral health-related quality of life. Eur J Oral Sci 2003;111:297-304.

20. Ni Riordain R, McCreary C. The use of quality of life measures in oral medicine: A review of the literature. Oral Dis 2010;16:419-30.

21. Caglayan F, Altun O, Miloglu O, Kaya MD, Yilmaz AB. Correlation between oral health-related quality of life (OHQoL) and oral disorders in a Turkish patient population. Med Oral Patol Oral Cir Bucal 2009;14:e573-8

22. Mumcu G, Niazi S, Stewart J, Hagi-Pavli E, Gokani B, Seoudi N, et al. Oral health and related quality of life status in patients from UK and Turkey: A comparative study in Behcet's disease. J Oral Pathol Med 2009;38:406-9. 
23. Mumcu G, Inanc N, Ergun T, Ikiz K, Gunes M, Islek U, et al. Oral health related quality of life is affected by disease activity in Behçet's disease. Oral Dis 2006;12:145-51.

24. Baker SR, Pankhurst CL, Robinson PG. Utility of two oral health-related quality-of-life measures in patients with xerostomia. Community Dent Oral Epidemiol 2006;34:351-62.

25. Hegarty AM, McGrath C, Hodgson TA, Porter SR. Patient-centred outcome measures in oral medicine: Are they valid and reliable? Int J Oral Maxillofac Surg 2002;31:670-4.

26. Locker D, Allen F. What do measures of 'oral health-related quality of life' measure? Community Dent Oral Epidemiol 2007;35:401-11.

27. Brennan DS, Spencer AJ. Dimensions of oral health related quality of life measured by EQ-5D and OHIP-14. Health Qual Life Outcomes 2004;2:35.

28. Reissmann DR, John MT, Schierz O. Influence of administration method on oral health-related quality of life assessment using the Oral Health Impact Profile. Eur J Oral Sci 2011;119:73-8.
29. Khalifa N, Allen PF, Abu-bakr NH, Abdel-Rahman ME. Psychometric properties and performance of the Oral Health Impact Profile (OHIP-14s-ar) among Sudanese adults. J Oral Sci 2013;55:123-32.

30. Inukai M, John MT, Igarashi Y, Baba K. Association between perceived chewing ability and oral health-related quality of life in partially dentate patients. Health Qual Life Outcomes 2010;8:118.

\begin{tabular}{|l|l|}
\hline \multicolumn{3}{|c|}{ Access this article online } \\
\hline Quick Response Code: & \\
\hline
\end{tabular}

